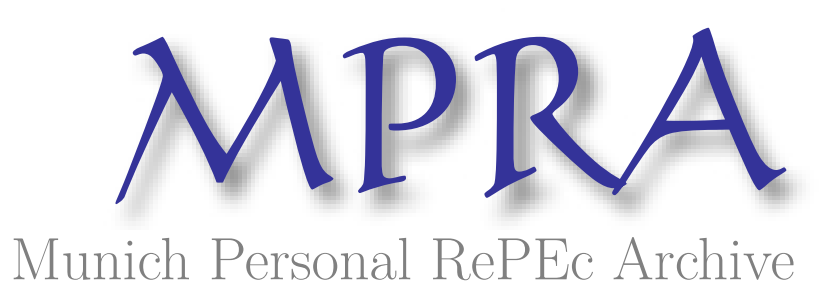

\title{
Econometric Analysis of Demand for Petrol in India, 1966-2019
}

Shaw, Charles

Independent

17 December 2020

Online at https://mpra.ub.uni-muenchen.de/104797/

MPRA Paper No. 104797, posted 24 Dec 2020 10:12 UTC 


\title{
Econometric Analysis of Demand for Petrol in India, 1966-2019
}

\author{
Charles SHAW
}

\begin{abstract}
This study uses single-equation dynamic models to estimate petrol demand in India. Estimated long-run elasticities are higher than their short-run counterparts, which is in line with expectations based on the existing literature. We find price elasticities of -0.418 (long-run) and -0.189 (short run), which indicates that when price increases by $10 \%$, demand tends to reduce by approximately $4 \%$ as consumers adjust their consumption behaviour. Prices appear to be more elastic in India rather than USA where studies estimate petrol elasticities to be in the range of -0.02 to -0.04 in the short term. We further find evidence that long-run elasticities are not as high as estimated elsewhere. We address issues around modelling of habit formation, habit persistence, and unobserved heterogeneity. Results are essential for transportation policymaking, especially in the context of taxation, understanding price stability, estimating the effects of duty increases on demand, and the potential implications for carbon taxes. The results are also important for wider policy considerations such as climate protections goals, reducing local emissions, dependency on fossil fuels, and strategic energy security.
\end{abstract}

Keywords: Energy modeling, Econometric modeling JEL Classification: Q41; Q42; Q48. 


\section{Contents}

List of Figures $\quad 2$

List of Tables $\quad 2$

1 Introduction and summary of relevant literature $\quad 3$

2 Empirical strategy $\quad \mathbf{4}$

2.1 Controlling for unobservable stock effects in the demand function. . . . . . . . . . . . . . 5

2.2 Augmenting Houthakker and Taylor (1966) with moving average errors. . . . . . . . . . . . 6

2.3 Modeling price reversibility . . . . . . . . . . . . . . . . . . 7

3 Data $\quad \mathbf{7}$

3.1 Augmented Dickey-Fuller test . . . . . . . . . . . . . . . . . . . . . 7

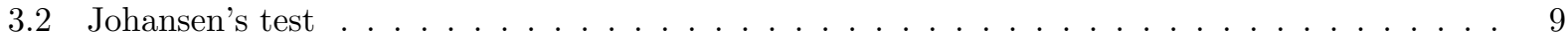

3.3 Granger causality (Toda-Yamamoto specification) . . . . . . . . . . . . . . . 10

4 Point estimates of price elasticities using the Delta method. 10

5 Results $\quad 11$

6 Conclusion $\quad 14$

$\begin{array}{lr}\text { Bibliography } & 16\end{array}$

\section{List of Figures}

1 Number of total vehicles and wages. . . . . . . . . . . . . . . . . . . 8

2 Petrol price index and GDI. . . . . . . . . . . . . . . . . . . . 8

3 Fitting a basic VAR model and graphing the orthogonalised IRFs . . . . . . . . . . . . . . . 10

\section{List of Tables}

Review of relates studies on elasticities of petrol demand . . . . . . . . . . . . . . . . . 4

Estimates from basic models. Models with and without time trends . . . . . . . . . . . 11

Estimates from basic models. Models with and without time trends . . . . . . . . . . . . 12

Estimates from basic models. Models with and without time trends . . . . . . . . . . . 13

Data used in sample, years 1966-2019. . . . . . . . . . . . . . . . . . . . . 15 


\section{Introduction and summary of relevant literature}

This study addresses transport petrol consumption in India. Specifically, we estimate price and income elasticities, both in the short-run and and in the long-run. We then make use of recent developments in the econometric literature to examine and address issues around modelling of habit formation, habit persistence, and unobserved heterogeneity.

Consumption of petrol (and related and petroleum products) is a well-studied topic, not least because it has important implications for economic policy. This is true especially in the context of price stability, the effects of petrol duty changes on demand, and the implications for carbon taxes.

There are a number of challenges with estimation, not least uncertainty of estimation caused by the complex and changing nature of petrol demand. Demand is a function of a number of human decisions that do not necessarily depend on cost, but also on unobservable preferences. Travel decisions are related to both professional and household decisions, which are highly dependent on context and habits.

Price and income elasticities of petrol demand are crucial if we are to capture demand response of consumers against a change in income or a change in price of oil. For policymakers this is of importance since it is possible to understand the the potential social welfare implications of energy pricing schemes, expected effects of rising energy prices on consumers, and related policy outcomes. The problem for researches is that the complex nature of petrol demand can introduce significant uncertainty of estimation. Petrol demand can be driven by various different decisions and factors. For example, travel decisions are strongly related to various household decisions, such as budget allocation, work and geographical preferences, weather conditions, situational factors such as trip purpose, passengers to carry, etc.

Related studies can be broadly separated according to two main dimensions. The first dimension is the region of interest. The second dimension is whether they use disaggregate or aggregate data sources. Studies that have used United States disaggregated data include Archibald and Gillingham (1980, [1]) Kayser (2000, [44]), Puller and Greening (1999, [51]), West and Williams (2007, [64]), and Wadud et al. (2010, [62]). US studies that use aggregated data include Hirota et al (2003, [30]), Austin and Dinan (2005,[3]), Hughes et al. (2008, [34], [35]), Hymel et al. (2010, [38],[39]), Lin and Prince (2013, [45]), Sentenac-Chemin (2012, [55]), Wadud et al. (2009, [61]. Examples of disaggregated data studies for European countries include Brannlund and Nordstrom (2004, [7]), Burguillo et al. (2017, [10]), and Romero-Jordan et al. (2010, [52]). Examples of aggregated data studies for European countries include Odeck and Johansen (2016, [48]), and Breunig and Gisz (2009, [8]). From US data, we can see that estimated short-term elasticities of petrol demand range from -0.03 to -0.51 , whilst long-term elasticities range from -0.239 to -0.473 . From global data, we can see that estimated short-term elasticities of petrol demand range from -0.09 to -0.36 , whilst long-term elasticities range from -0.2 to -0.81 . Table 1 presents a brief summary of related literature. 
Table 1: Review of relates studies on elasticities of petrol demand

\begin{tabular}{|c|c|c|c|c|}
\hline Source & Observation period & Geographic region & Elasticity, Short term & Elasticity, Long term \\
\hline Breunig and Gisz (2009)c & $1966-2006$ & Australia & -0.13 & -0.2 \\
\hline Odeck and Johansen (2016) & 1980-2011 & Norway & -0.26 & 0.09 \\
\hline Burguillo et al. (2017) & 1998-2005 & Spain & -0.35 to $-0.49 \mathrm{e}$ & \\
\hline Romero-Jordán et al. (2010) & 1998-2001 & Spain & - & -0.55 \\
\hline Brännlund and Nordström (2004) & 1985-1992 & Sweden & - & -0.98 \\
\hline Austin and Dinan (2005) & 2001 & USA & - & -0.39 \\
\hline Hughes et al. (2008)b & $1975-1980$ & USA & -0.275 & - \\
\hline Hughes et al. (2008)b & $2001-2006$ & USA & -0.056 & - \\
\hline Hymel et al. (2010) & 1966-2004 & USA & -0.075 & -0.361 \\
\hline Hymel et al. (2010)b & 2004 & USA & -0.055 & -0.285 \\
\hline Lin and Prince (2013)c & 1990-2012 & USA & -0.03 & -0.239 \\
\hline Sentenac-Chemin (2012)c & $1978-2005$ & USA & - & -0.3 \\
\hline Wadud et al. (2009) & $1984-2003$ & USA & -0.266 & - \\
\hline Archibald and Gillingham (1980) & $1972-1973$ & USA & -0.43 & - \\
\hline Kayser (2000)b & 1981 & USA & -0.23 & \\
\hline Puller and Greening (1999) & 1980-1990 & USA & -0.35 & - \\
\hline Wadud et al. (2010a) & $1997-2002$ & USA & & -0.473 \\
\hline West and Williams (2007) & $1996-1998$ & USA & -0.51 & - \\
\hline Brons et al. (2008)a & 1972-1999 & Worldwide & -0.36 & -0.81 \\
\hline Burke and Nishitateno (2013)c & $1995-2008$ & Worldwide & - & -0.2 to -0.5 \\
\hline Dahl (2012)a,c & 1954-2005 & Worldwide & -0.15 & -0.55 \\
\hline Dahl (2012)a,d & 1954-2005 & Worldwide & -0.10 & -0.33 \\
\hline Goodwin et al. (2004) & 1981-1991 & Worldwide & -0.16 & -0.43 \\
\hline Goodwin et al. (2004)a & 1974-1981 & Worldwide & -0.35 & -0.93 \\
\hline Havranek et al. (2012)a,c & $1974-2011$ & Worldwide & -0.09 & -0.31 \\
\hline Hirota et al. (2003) & 1990-2002 & Worldwide & -0.195 & - \\
\hline
\end{tabular}

\section{Empirical strategy}

Single-equation studies have their origin in dynamic demand models of 1960's a la Balestra-Nerlove ([4]) and Houthakker-Taylor ([31],[33]). Demand for durable goods in this context is examined using a partial adjustment mechanism where both stockpiling and habit-forming play a role. This leads to a general dynamic theory of utility maximisation. In such models, the stock of a durable good is a function of the gap between past stock and current (desired) stock levels; see See Taylor et al [32] for an extensive survey.

Such models have been fruitfully applied to petrol consumption. For example, Baltagi and Griffin ([6]) use the idea of partial adjustments driven by a fixed vehicle stock as follows:

$$
\nu_{t}^{*} \equiv\left(\frac{V^{*}}{N}\right)_{t}=k_{1}\left(\frac{P_{g}}{P}\right)_{t}^{k 2}\left(\frac{Y}{N}\right)_{t}^{k 3}\left(\frac{C a r}{N}\right)_{t-1}^{k 4} \epsilon_{t}
$$

where $\nu_{t}^{*}$ corresponds to consumption of petrol per capita at time $t$, Car corresponds to the stock of cars, $N$ is the population, $Y$ is real income, $P$ is the aggregate price level, $P_{g}$ is the price of petrol, $V^{*}$ is the desired volume of petrol consumption, and $\epsilon_{t}$ is the error term, assumed to be white noise i.i.d.

Since the adjustment is not necessarily instantaneous, we model it as follows:

$$
\nu_{t}=\left(\nu_{t}^{*}\left(\nu_{t}^{*}\right)^{\theta}\left(\nu_{t-1}\right)^{1-\theta}\right.
$$

when $\theta=1$ then $\nu_{t}^{*}=\nu_{t}$ i.e. there is instant adjustment of desired to actual consumption. In the case of petrol this is possible but unlikely, since there exist a number of factors which determine the "stickiness" of demand. If we consider transportation-related factors alone, then these can include e.g. commuting habits and geographic dispersion of residential property, which in the short run tends to be fixed. We are able to re-arrange and combine equations 1 and 2 to yield a useful model for observed petrol consumption per person 


$$
\nu_{t}=k_{1}^{\theta}\left(\frac{P_{g}}{P}\right)_{t}^{k 2 \theta}\left(\frac{Y}{N}\right)_{t}^{k 3 \theta}\left(\frac{C a r}{N}\right)_{t-1}^{k 4 \theta} \nu_{t-1}^{1-\theta} \epsilon_{t}^{\theta}
$$

We further fix the notation of equation 3 individual for real variables and per-individual and take logs, which yields the well-utilised in the literature specification (e.g. [5], [20], [6], [24], [17], [42], [15], see [28] for a survey):

$$
\nu_{t}=k_{1}^{\theta}\left(p_{t}\right)_{t}^{k 2 \theta}\left(y_{t}\right)_{t}^{k 3 \theta}\left(\operatorname{car}_{t-1}\right)_{t-1}^{k 4 \theta} \nu_{t-1}^{1-\theta} \epsilon_{t}^{\theta}
$$

If we impose a restriction where $\beta_{c}=0^{1}$ then we obtain

$$
\begin{aligned}
\ln \left(\nu_{t}\right)=\theta \ln \left(k_{1}\right)+\theta k_{2} \ln \left(p_{t}\right)+k_{3} \theta \ln \left(y_{t}\right) & +k_{4} \theta \ln \left(\operatorname{car}_{t-1}\right)+(1-\theta) \ln \left(\nu_{t-1}\right)+\theta \ln \left(\epsilon_{t}\right) \\
& =\beta_{0}+\beta_{p} \ln \left(p_{t}\right)+\beta_{y} \ln \left(y_{t}\right)+\beta_{\nu} \ln \left(\nu_{t-1}\right)+\beta_{c} \ln \left(\operatorname{car}_{t-1}\right)+\epsilon_{t}
\end{aligned}
$$

We then extend model 5 as per [8] by including lagged values of $\nu_{t}$ in order to account for the possibility that adjustment of actual to desired consumption may last greater than single period. We can then estimate the following model:

$$
\ln \left(\nu_{t}\right)=\beta_{0}+\beta_{p} \ln \left(p_{t}\right)+\beta_{y} \ln \left(y_{t}\right)+\sum_{j=1}^{q} \beta_{\nu q} \ln \left(\nu_{t-q}\right)+\epsilon_{t}
$$

Model 5 has a limitation, which is its inability to capture persistence of current consumption habits ([54], [45]). On the other hand, it is possible to address this issue by incorporating moving average terms. But on the other hand, this would make standard OLS estimation inconsistent. Model 6 also has a limitation, which relates to price reversibility. The implication here is that demand response to a rise in prices is identical to demand response to a fall in prices. This assumption may be too strong to aceept. We follow [8] and address this constraint with a relatively enhanced specification.

\subsection{Controlling for unobservable stock effects in the demand function.}

We have derived a model which depends on relative prices and real income. Now let us consider a model for petrol consumption at a given time $t$ which is a function of not only real income and relative prices and real income, but also some unobservable stock parameter, $s_{t-1}^{*}$. This parameter captures habitual (i.e. psychological) determinants of petrol consumption. It also captures physical determinants, such as commuter dispersion, and vehicle efficiency. We are able to state a new specification as follows:

$$
\ln \left(\nu_{t}\right)=\alpha_{1}+\alpha_{2} \ln \left(p_{t}\right)+\alpha_{3} \ln \left(y_{t}\right)+\alpha_{4} s_{t-1}^{*}+w_{t}
$$

Urban layouts, habits, and other such determinants evolve according to

$$
\Delta s^{*} \equiv s^{*}-s_{t-1}^{*}=\ln \left(\nu_{t}\right)-\delta s_{t-1}^{*}
$$

\footnotetext{
${ }^{1}$ In other words, we assume that stocks of vehicles are constant.
} 
Equation 8 is essentially identical to a standard capital equipment model, where $\delta$ would correspond to the rate of depreciation. However, in our specification we use the parameter $\delta$ to control for the speed at which the determinants of petrol consumption adjust. Setting $\delta=1$ is the same as setting $\theta=1$ in model 2 .

By setting $\delta=1$, model 7 collapses to model 5. Estimating 5 is equivalent to imposing an assumption that there exist no 'stock effects' (either habitual or physical) to past consumption that affect current consumption. For petrol consumption this is assumption is not realistic because we know that habits exhibit a strong effect on consumption. These can include the following channels, some of which can be persistent $([56,34])$ :

In the short-run:

- Behavioural habits. Demand is determined by trip frequency, vehicle upkeep, driving style, and carpooling.

In the long-run:

- Location choice. Considerations regarding where to work and live determine commuting distance.

- Vehicle choice. Considerations regarding petrol efficiency determine petrol consumption.

- Availability of cycling paths, public transport, etc.

To mitigate for this restrictive assumption, we aim to rewrite the Houthakker-Taylor model.

\subsection{Augmenting Houthakker and Taylor (1966) with moving average errors.}

We reparametrise equation 7 by writing $\Delta \ln \left(\nu_{t}\right)$, substituting equation 8 , adding a lag to equation 7 , and replacing $s_{t-2}^{*}$ in $\Delta \ln \left(\nu_{t}\right)$.

$$
\ln \left(\nu_{t}\right)=\alpha_{1} \delta+\alpha_{2} \delta \ln \left(p_{t-1}\right)+\alpha_{2} \Delta \ln \left(p_{t}\right)+\alpha_{3} \delta\left(y_{t-1}\right)+w_{t}-(1-\delta) w_{t-1}
$$

After further rearranging model 10 we get model 11. The benefit of doing this is that we get a model with a moving average component:

$$
\ln \left(\nu_{t}\right)=\gamma_{0}+\gamma_{p} \ln \left(p_{t-1}\right)+\gamma_{\Delta_{p}} \Delta \ln \left(p_{t}\right)+\gamma_{y} \ln \left(y_{t-1}\right)+\gamma_{\Delta_{y}} \Delta \ln \left(y_{t}\right)+\gamma_{\nu} \ln \left(\nu_{t-1}\right)+u_{t}
$$

Stock adjustment may take longer than one period. Hence, we replace model 8 with the below specification.

$$
s^{*}=\ln \left(\nu_{t}\right)+(1-\delta) s_{t-1}^{*}+\sum_{j=2}^{q} \delta_{j} s_{t-j}^{*}
$$

And finally, we combine models 7 and 11 to get

$$
\ln \left(\nu_{t}\right)=\gamma_{0}+\sum_{j=1}^{q} \gamma_{p j} \ln \left(p_{t-j}+\gamma_{\Delta_{p}} \Delta \ln \left(p_{t}\right)+\sum_{j=1}^{q} \gamma_{y j} \ln \left(y_{t-j}+\gamma_{\Delta_{y}} \Delta \ln \left(y_{t}\right)+\sum_{j=1}^{q} \gamma_{\nu j} \ln \left(\nu_{t-j}+u_{t}\right.\right.\right.
$$

The above model has the advantage of being flexible in the sense that the parameters which determine the short-run and the long-run elasticities are estimated separately. This is in direct opposition of model 6 . 


\subsection{Modeling price reversibility}

Following [17], we aim to identify different effects on consumption of price decreases and vs increases. To do this we replace introduce three constructed price series in the above equations

$$
\begin{gathered}
\ln (p)_{t}^{+}=\sum_{s=2}^{t}\left[\left(\ln (p)_{s}-\ln (p)_{s-1}\right)-\left(\ln (p)_{s}^{\max }-\ln (p)^{(} \max \right)_{s-1}\right] \mathbb{1}\left(\ln (p)_{s}>\ln (p)_{s-1}\right) \\
\ln (p)_{t}^{-}=\sum_{s=2}^{t}\left[\ln (p)_{s}-\ln (p)_{s-1}\right] \mathbb{1}\left(\ln (p)_{s}>\ln (p)_{s-1}\right) \\
\ln (p)_{t}^{\max }= \begin{cases}\ln (p)_{1} & \text { if } t=1 \\
\ln (p)_{t} & \text { if } \ln (p)_{t}>\ln (p)_{s} \forall s<t \\
\ln (p)_{t-1} & \text { if } \ln (p)_{t}=\ln (p)_{t-1}\end{cases}
\end{gathered}
$$

where $\mathbb{1}(\cdot)$ is an indicator function which equals unity if the expression in brackets is true, zero if it is not. $\ln (p)_{t}^{+} / \ln (p)_{t}^{-} / \ln (p)_{t}^{\max }$ corresponds to the cumulative series of sub-maximum price increases / price decreases / max historical prices respectively. Using the following property,

$$
\ln (p)_{t}=\ln (p)_{t}^{+}+\ln (p)_{t}^{-}+\ln (p)_{t}^{\max }
$$

we get specification 15 , which is our final model to be estimated

$$
\ln \left(\nu_{t}\right)_{t}=\beta_{0}+\beta_{p \max } \ln (p)_{t}^{\max }+\beta_{p+} \ln (p)_{t}^{+}+\beta_{p-}+\ln (p)_{t}^{-}+\beta_{y}+\ln (y t)+\beta_{\nu}+\ln \left(\nu_{t-1}\right)+\epsilon_{t}
$$

\section{Data}

We make use of data from Indian Ministry of Road Transport and Highways, BP Statistical Review of World Energy, IMF Government Finance Statistics, and World Bank national accounts data. Obtaining more nuanced data of this kind has posed some minor challenges which forced some modelling choices. For example, it could be interesting to reparametrise equations 1 and 2 in order to capture effects of heterogeneity of vehicles where our model could incorporate parameters relating to the current stock of cars, such as age, vehicle utilisation, $\mathrm{CO} 2$ /particulates emissions, or petrol efficiency. To this extend, we made enquiries to the Indian Civil Service so that we could obtain these data. However, this request was not successful. Apparently, the Ministry of Petroleum and Natural Gas was earlier part of Ministry of Chemicals and Fertilisers and this departmental change affected the way historical data is collated and archived. Table 5 outlines the main data sourced for this study. Reliable petrol price data were not obtainable prior to the start of our sample period.

\subsection{Augmented Dickey-Fuller test}

We conduct a Augmented Dickey-Fuller test for unit root. The data shows a clear upward trend, we use the trend option with dfuller to include a constant and time trend (consumption grows over time) in the augmented Dickey-Fuller regression. Results show that we can overwhelmingly reject the null hypothesis of a unit root at all common significance levels. From the regression output, the estimated $\beta$ of -.63002 implies that $\rho=(1-.6300)=0.37$. Experiments with fewer or more lags in the augmented regression yield analogous conclusions. ${ }^{2}$

\footnotetext{
${ }^{2}$ As the ADF test is underpowered, we conduct a KPSS test with the null of stationarity against the alternative hypothesis of a unit root. Results do not change.
} 


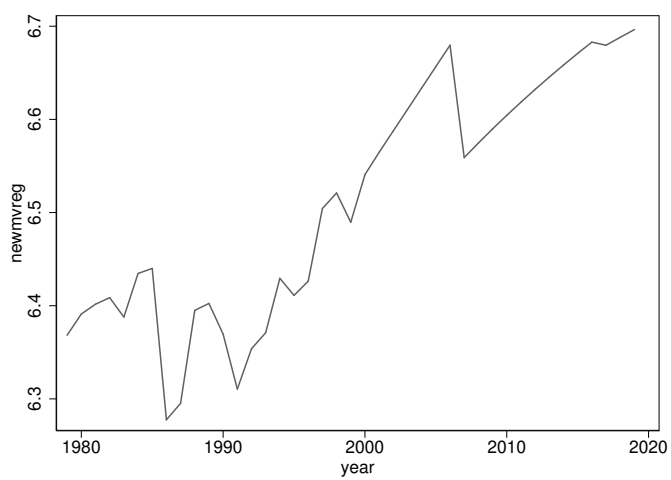

(a) Number of total vehicles. (Index, $1966=100$ ).

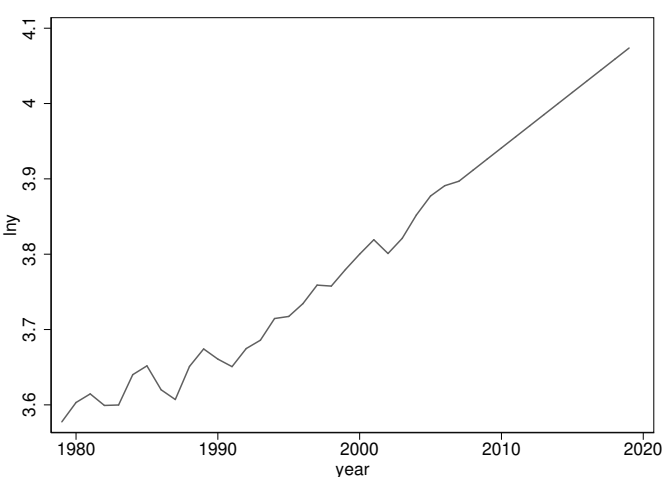

(b) Aggregate income - wages and profits. (Index, $1966=$ 100).

Figure 1: Number of total vehicles and wages.

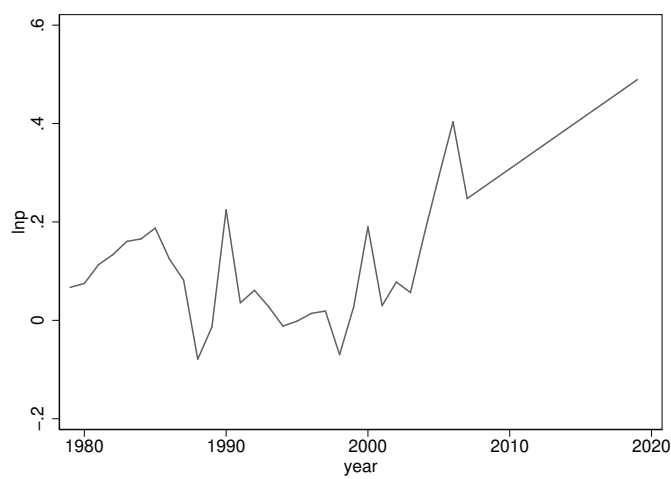

(a) Petrol Price Index (Index, $1966=100)$.

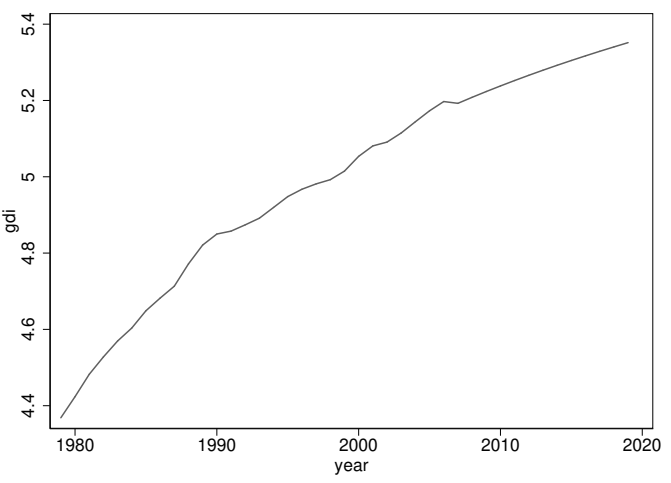

(b) Aggregate income - wages and profits. (Index, $1966=$ 100).

Figure 2: Petrol price index and GDI. 


\subsection{Johansen's test}

This test has a limitation in the sense that it relies on asymptotic properties and sensitive to specification errors in limited samples. After plotting logged consumption vs price index, it is clear that our variables indicate trend together. We now perform a unit root test to see if our data are stationary at same level. We use AIC as the lag selection criteria. The results show that all the variables exhibit non-stationarity in level (at $1 \%$ significance level) but they show stationarity for the first difference. We conclude that our variables of interest are I $(1)^{3}$.

As as an entry point to further analysis, we fit a basic vector autoregressive (VAR) model and graph the orthogonalised impulse-response functions (OIRFs). Figure 3 shows this simple reduced-form VAR without constraints. The graph of impulse-response functions (IRFs) indicates that shocks are likely to correlated. We then use AIC as a lag order selection statistic for a series of vector autoregressions of order $1, \ldots, 10$. Our information criterion shows that the appropriate lag is 1 .

When we apply Johansen approach [41], we need to select the deterministic elements of the model in order to recognise if deterministic components (constant or a time trend), are included in levels or cointegration equation. Clearly, cointegration tests are specification-sensitiveand the distribution of the test statistics varies for each combination. In this regard, we can make the following test choices.

- Model 1: no deterministic trend in data and no intercept or trend in cointegration equation (CE);

- Model 2: no linear trend in data but an intercept (no trend) in CE;

- Model 3: a linear trend in data and intercept (no trend) in CE;

- Model 4: a linear trend in data, while intercept and trend exist in CE;

- Model 5: a quadratic deterministic trend in data, intercept and trend in CE.

We only consider 2 (most restrictuve), 3 , and, 4 (least restrictive). After we determine the appropriate lag length, we start from the most and continue to least restrictive model (Pantula principle), comparing the rank statistic is compared with its concordant critical value.

Since $\lambda_{\text {trace }}$ at $r=0$ exceeds its critical value at $5 \%$ level, we reject the null of no cointegration equations. But since at $r=1$, the $\lambda_{\text {trace }}$ is less than its critical value at $5 \%$ level, we thus fail to reject the null that only one cointegration equations exist. In other words, the Johansen procedure indicates that a cointegration relationship exist between petrol prices and volume of petrol consumed. We were able to find one analysis in the literature that in this regard is close to this study, specifically [43] investigate cointegration among petrol demand, real price of petrol, and real GDP for India for the period 1971-1972 and 2012-2013. They also estimates short-run and long-run elasticity of petrol demand with respect to its price and GDP. Johansen-Juselius and ARDL bounds test methods establish that petrol demand, petrol price, and GDP are cointegrated. Regime shift cointegration tests with endogenous structural breaks, confirm cointegration between gasoline demand and GDP. We note this result but in line with other studies in the literature, and in light of our univariate unit root test results, we do not feel the need to amend the econometric specification beyond the adjustments which were already discussed earlier in Section 2.

In line with other studies in the field of energy economics $([2,3,7,9,12,13,25,26,35,8]$, etc), we also consider the impact of the crude oil shocks in the late 1970s. One such shock was the 1979 Oil Crisis, which was caused by the Iranian Revolution. To test the hypothesis of unit root on pre-1978 and post- 1979 data we would ideally like to have more observationa. Regrettably, we were not able to obtain quarterly data from the Indian Civil Service and the best we could rely on was annual-frequency data. Analogously, data from such public sources as World Bank, BP Statistical Review, and IMF is only available on an annual frequency.

\footnotetext{
${ }^{3}$ We conducted the KPSS test to remove the suspicion that our time-series is fractionally integrated (that is, neither I(1) nor $\mathrm{I}(0))$.
} 


\subsection{Granger causality (Toda-Yamamoto specification)}

Next, we look at Granger causality. In line with our theoretical expectations, the Toda-Yamamoto ([59]) specification of the Granger causality test indicates long-term unidirectional (Granger) causality from real income to petrol consumption.

Figure 3: Fitting a basic VAR model and graphing the orthogonalised IRFs
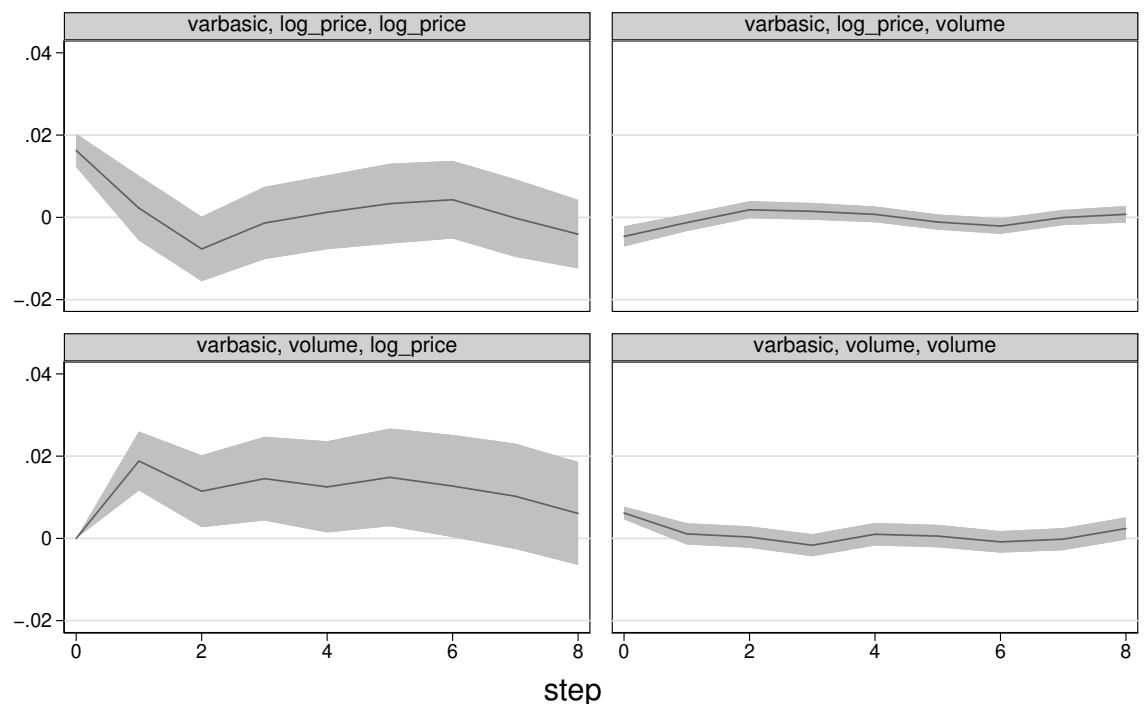

step

$95 \% \mathrm{Cl}$ orthogonalized irf

Graphs by irfname, impulse variable, and response variable

\section{Point estimates of price elasticities using the Delta method.}

We make use of Stata's 'nlcom' command that implements the delta method to convert the confidence intervals to those obtained directly from the least squares regression. The delta method approximates the expectation of some function $g(\cdot)$ of a r.v. $x$ by taking a (truncated) Taylor expansion. It can be shown ([1]) under relatively weak conditions for any parameter $\theta$ that is approximately Gaussian in its sampling distribution with variance $\sigma^{2} / n$, the sampling distribution of $g(\theta)$ is also approximately normal with variance $\left[g^{\prime}(\theta)\right]^{2} \sigma^{2} / n$. This is because $g(\cdot)$ is approximately linear around $\theta$. Stata's function nlcom is used for this purpose. 


\section{Results}

Table 2: Estimates from basic models. Models with and without time trends

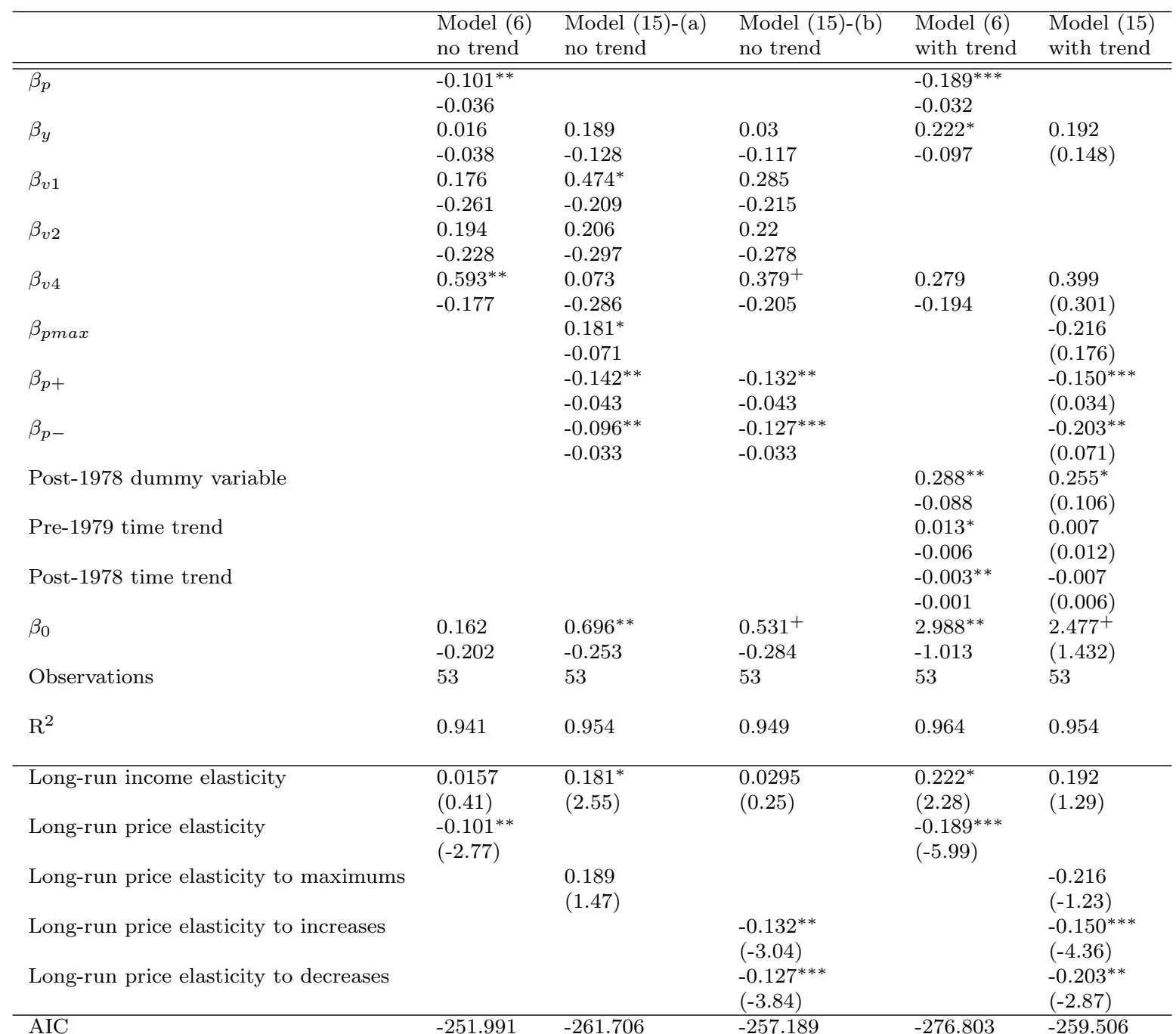

All models are estimated by OLS with White-Huber robust standard errors. Lags in columns (a), (b), and (c) are selected by AIC. Using standard model selection criteria, Model (b) is preferred to models (a) or (c), while model (d) is preferred to model $(\mathrm{e}) .+{ }^{+},{ }^{* *} * * *$ indicate statistical significance levels at $10 \%, 5 \%, 1 \%$, and $0.1 \%$ respectively. The irreversible model is rejected in favour of the standard reversible model once time trends are included in the model. 
Table 3: Estimates from basic models. Models with and without time trends

\begin{tabular}{|c|c|c|c|c|}
\hline & $\begin{array}{l}\text { Model (6) } \\
\text { no trend }\end{array}$ & $\begin{array}{l}\text { Model (15) } \\
\text { no trend }\end{array}$ & $\begin{array}{l}\text { Model }(6) \\
\text { time trend }\end{array}$ & $\begin{array}{l}\text { Model }(15) \\
\text { time trend }\end{array}$ \\
\hline$\beta_{p}$ & $\begin{array}{l}-0.120^{* *} \\
-0.037\end{array}$ & & $\begin{array}{l}-0.151^{* *} \\
-0.048\end{array}$ & \\
\hline$\beta_{y}$ & $\begin{array}{l}-0.022 \\
-0.045\end{array}$ & $\begin{array}{l}0.063 \\
-0.151\end{array}$ & $\begin{array}{l}0.219 \\
-0.19\end{array}$ & $\begin{array}{l}0.155 \\
(0.251)\end{array}$ \\
\hline$\beta_{v 1}$ & $\begin{array}{l}0.450^{*} \\
-0.181\end{array}$ & $\begin{array}{l}0.503^{*} \\
-0.206\end{array}$ & $\begin{array}{l}0.440^{*} \\
-0.184\end{array}$ & $\begin{array}{l}0.505^{*} \\
(0.208)\end{array}$ \\
\hline$\beta_{v 4}$ & $\begin{array}{l}0.13 \\
-0.19\end{array}$ & $\begin{array}{l}0.156 \\
-0.224\end{array}$ & $\begin{array}{l}0.128 \\
-0.199\end{array}$ & $\begin{array}{l}0.150 \\
(0.294)\end{array}$ \\
\hline$\beta_{p \max }+$ & & $\begin{array}{l}-0.118^{+} \\
-0.059\end{array}$ & & \\
\hline$\beta_{p-}$ & & $\begin{array}{l}-0.101^{*} \\
-0.039\end{array}$ & & $\begin{array}{c}-0.134^{+} \\
(0.079)\end{array}$ \\
\hline Post-1978 time trend & & & $\begin{array}{l}-0.003 \\
-0.002\end{array}$ & $\begin{array}{l}-0.004 \\
(0.005)\end{array}$ \\
\hline$\beta_{p \max }$ & & & & $\begin{array}{l}-0.097 \\
(0.156)\end{array}$ \\
\hline$\beta_{p+}$ & & & & $\begin{array}{c}-0.112^{+} \\
(0.057)\end{array}$ \\
\hline$\beta_{0}$ & $\begin{array}{l}2.43 \\
-1.482\end{array}$ & $\begin{array}{l}1.707 \\
-1.606\end{array}$ & $\begin{array}{l}1.679 \\
-1.429\end{array}$ & $\begin{array}{l}1.422 \\
(1.656)\end{array}$ \\
\hline Observations & 41 & 41 & 41 & 41 \\
\hline $\mathrm{R}^{2}$ & 0.882 & 0.856 & 0.892 & 0.857 \\
\hline Long-run income elasticity & & & & $\begin{array}{l}0.155 \\
(0.62)\end{array}$ \\
\hline Long-run price elasticity & & & & \\
\hline Long-run price elasticity to maximum & & & & \\
\hline Long-run price elasticity to increases & & $\begin{array}{l}-0.118 \\
(-2.00)\end{array}$ & & $\begin{array}{c}-0.112 \\
(-1.97)\end{array}$ \\
\hline Long-run price elasticity to decreases & & $\begin{array}{l}-0.101^{*} \\
(-2.61)\end{array}$ & & $\begin{array}{l}-0.134 \\
(-1.69)\end{array}$ \\
\hline $\mathrm{AIC}$ & -221.959 & -211.828 & -223.559 & -208.188 \\
\hline
\end{tabular}

Column (b) includes the restriction $\beta_{p \max }=\beta_{p+}$. All models are estimated by OLS with White-Huber robust standard errors. Lags in columns (a), (b), and (c) are selected by AIC. Using standard model selection criteria, Model (a) is preferred to models (b), while model (c) is preferred to model (d). $+,{ }^{*}, * * * * *$ indicate statistical significance levels at $10 \%, 5 \%, 1 \%$, and $0.1 \%$ respectively. As in Table 2 , the irreversible model is rejected in favour of the standard reversible model once time trends are included in the model. 
Table 4: Estimates from basic models. Models with and without time trends

\begin{tabular}{|c|c|c|c|}
\hline & Model (12)-(a) & Model (12)-(b) & Model (12)-(c) \\
\hline \multirow[t]{2}{*}{$\gamma_{p 1}$} & -0.042 & -0.065 & $-0.073^{*}$ \\
\hline & -0.031 & -0.048 & $(0.034)$ \\
\hline \multirow[t]{2}{*}{$\gamma_{\Delta 1}$} & $-0.392^{* * *}$ & $-0.373^{* * *}$ & $-0.418^{* * *}$ \\
\hline & -0.065 & -0.069 & $(0.058)$ \\
\hline \multirow[t]{2}{*}{$\gamma_{y 1}$} & $-0.367^{*}$ & -0.262 & -0.252 \\
\hline & -0.172 & -0.207 & $(0.156)$ \\
\hline \multirow[t]{2}{*}{$\gamma_{\Delta y}$} & -0.337 & -0.223 & $-0.395^{+}$ \\
\hline & -0.218 & -0.291 & $(0.211)$ \\
\hline \multirow[t]{2}{*}{$\gamma_{p 3}$} & -0.033 & -0.031 & \\
\hline & -0.028 & -0.031 & \\
\hline \multirow[t]{2}{*}{$\gamma_{y 3}$} & -0.054 & -0.01 & \\
\hline & -0.189 & -0.215 & \\
\hline \multirow[t]{2}{*}{$\gamma_{p 4}$} & -0.003 & 0.001 & -0.020 \\
\hline & -0.021 & -0.022 & $(0.020)$ \\
\hline \multirow[t]{2}{*}{$\gamma_{y 5}$} & $0.427^{*}$ & $0.395^{*}$ & $0.332^{*}$ \\
\hline & -0.181 & -0.184 & $(0.161)$ \\
\hline \multirow[t]{2}{*}{$\gamma_{v 1}$} & $0.716^{* * *}$ & $0.687^{* * *}$ & $0.642^{* * *}$ \\
\hline & -0.119 & -0.14 & $(0.114)$ \\
\hline \multirow[t]{2}{*}{$\gamma_{v 3}$} & -0.197 & -0.239 & \\
\hline & -0.191 & -0.209 & \\
\hline \multirow[t]{2}{*}{$\gamma_{v 4}$} & 0.16 & 0.174 & 0.110 \\
\hline & -0.159 & -0.168 & $(0.142)$ \\
\hline \multirow[t]{2}{*}{ Post-1978 time trend } & & -0.001 & -0.001 \\
\hline & & -0.002 & $(0.001)$ \\
\hline \multirow[t]{2}{*}{$\gamma_{0}$} & 1.786 & 1.707 & 1.129 \\
\hline & -1.364 & -1.494 & $(1.248)$ \\
\hline Observations & 41 & 41 & 41 \\
\hline $\mathrm{R}^{2}$ & 0.951 & 0.952 & 0.947 \\
\hline \multirow[t]{2}{*}{ Long-run income elasticity } & $-0.367^{*}$ & -0.223 & -0.395 \\
\hline & $(-2.13)$ & $(-0.77)$ & $(-1.87)$ \\
\hline \multirow[t]{2}{*}{ Long-run price elasticity } & $-0.392^{* * *}$ & $-0.373^{* * *}$ & $-0.418^{* * *}$ \\
\hline & $(-6.07)$ & $(-5.40)$ & $(-7.22)$ \\
\hline $\mathrm{AIC}$ & -244.033 & -242.974 & -244.769 \\
\hline
\end{tabular}

All models are estimated by OLS with White-Huber robust standard errors. Lags in columns (a), (b), and (c) are selected by AIC. Using standard model selection criteria, Model (a) is preferred to models (b), while model (c) is preferred to model (d). $+, *, * * * *$ indicate statistical significance levels at $10 \%, 5 \%, 1 \%$, and $0.1 \%$ respectively. 


\section{Conclusion}

India's oil demand has soared over the last few years, reaching an average figure for oil demand growth $\mathrm{y} / \mathrm{y}$ of $0.40 \mathrm{mb} / \mathrm{d}$ in 2018 , compared with $0.1-0.15 \mathrm{mb} / \mathrm{d}$ over the previous decade. This rise in demand could have implications for India's recently acquired status as a net exporter of petroleum products. In comparison, China's oil demand has slowed to around $0.30 \mathrm{mb} / \mathrm{d}$ from levels of $0.50 \mathrm{mb} / \mathrm{d}$ in the previous decade.

To shed light on this crucial area, we uses single-equation dynamic models to estimate petrol demand in India using a data set compiled from Indian Ministry of Road Transport and Highways (and augmented national accounts data). We find price elasticities of -0.418 (long-run) and -0.189 (short run), which indicates indicates that when price increases by $10 \%$, demand reduces by approx $4 \%$ in a reasonably long period of time that allows the consumers to adjust their consumption behaviour.

Estimated long-run elasticities are higher than their short-run counterparts, which is in line with expectations based on the existing literature. We find price elasticities of -0.418 (long-run) and -0.189 (short run), which indicates indicates that when price increases by $10 \%$, demand reduces by approx $4 \%$ in a reasonably long period of time that allows the consumers to adjust their consumption behaviour. Prices appear to be more elastic in India rather than say USA where studies estimate petrol elasticities to be in the range of - 0.02 to -0.04 in the short term.

We find similar evidence for short-term demand elasticities as elsewhere in the literature $([2,3,7,9,12,13$, $25,26,35,37])$. On the other hand, we find evidence that long-run elasticities are not as high as estimated elsewhere. For example, Oxford Institute for Energy Studies $[2,3]$ estimates the long-run demand elasticities for petrol and gasoline to be around 1. Our finding support previous estimates by Burke and Nishitateno [12] who estimate the worldwide petrol demand elasticities to be between -0.2 to -0.5 .

Our testing indicates long-term unidirectional (Granger) causality from real income to petrol consumption. The direction matters. If there was unidirectional Granger causality running from petrol consumption to economic growth, then reducing petrol consumption could put downward pressure on national income. Alternatively, if there was evidence of unidirectional Granger causality running from economic growth to petrol consumption then one could suggest that reducing consumption through energy conservation and demand side measures would not be a detriment on economic growth. 
Table 5: Data used in sample, years 1966-2019.

\begin{tabular}{ll}
\hline Variable & Source \\
\hline \hline Petrol consumption & bp Statistical Review of World Energy 2020 \\
Male and female average earnings & International Monetary Fund, Government Finance Statistics \\
GNP (current US\$) & World Bank national accounts data \\
Population & United Nations Population Division's World Population Prospects: 2020 Revision. \\
CPI & International Monetary Fund, International Financial Statistics and data files. \\
Petrol Price Index & Ministry of Petroleum \& Natural Gas, Government of India. https:/ppac.gov.in \\
Registered Motor Vehicles in India & Indian Ministry of Road Transport and Highways. https://data.gov.in \\
Petrol consumption & Ministry of Petroleum \& Natural Gas, Government of India
\end{tabular}




\section{Bibliography}

[1] Agresti, Alan. 2002. Categorical Data Analysis. 2 ed. Hoboken: John Wiley.

[2] Archibald, R., Gillingham, R., 1980. An analysis of the short-run consumer demand for gasoline using household survey data. Rev. Econ. Stat. 62, 622-628.

[3] Austin, D., Dinan, T., 2005. Clearing the air: the costs and consequences of higher CAFE standards and increased gasoline taxes. J. Environ. Econ. Manage. 50, 562-582.

[4] Balestra, P. and Nerlove, M. (1966). Pooling cross section and time series data in the estimation of a dynamic model: The demand for natural gas. Econometrica, 34(3):585-612.

[5] Baltagi, B. H. and Griffin, J. M. (1983). Gasoline demand in the OECD: An application of pooling and testing procedures. European Economic Review, 22:117-137.

[6] Baltagi, B. H. and Griffin, J. M. (1997). Pooled estimators vs. their heterogeneous counterparts in the context of dynamic demand for gasoline. Journal of Econometrics, 77:303-327.

[7] Brannlund, R., Nordstrom, J., 2004. Carbon tax simulations using a household demand model. Eur. Econ. Rev. 48 (2004), 211-233.

[8] Breunig, R. and C. Gisz (2009), An exploration of Australian petrol demand: unobservable habits, irreversibility, and some updated estimates. Economic Record, Volume 85, Number 268, pp. 73-91.

[9] Brons, M., Nijkamp, P., Pels, E., Rietveld, P., 2008. A meta-analysis of the price elasticity of gasoline demand. A SUR approach. Energy Econ. 30, 2105-2122.

[10] Burguillo M., P. Del Río, D. Romero-Jordán (2017) Car use behaviour of Spanish households: differences for quartile income groups and transport policy implications. Case Stud. Transp. Policy, 5 (2017), pp. 150-158

[11] Burke, P.J., Nishitateno, S., 2013. Gasoline prices, gasoline consumption, and new-vehicle fuel economy: evidence for a large sample of countries. Energy Econ. 36, 363-370.

[12] Burke, P.J., Nishitateno, S., 2013. Gasoline prices, gasoline consumption, and new-vehicle petrol economy: evidence for a large sample of countries. Energy Econ. 36, 363-370.

[13] Dahl, C.A., 2012. Measuring global gasoline and diesel price and income elasticities. Energy Policy 41, 2-13.

[14] Dargay, J. (2007). 'The Effect of Prices and Income on Car Travel in the UK.' Transportation Research Part A: Policy and Practice 41A (10): 949-960.

[15] Dargay, J. and Gately, D. (1997). The demand for transportation fuels: imperfect price-reversibility? Transportation Research B, 31(1):71-82.

[16] Dargay, J. M. (1992). The irreversible demand effects of high oil prices: Motor fuels in France, Germany, and the UK. In Hawdon, D., editor, Energy Demand: Evidence and Expectations. Academic Press, New York, NY.

[17] Dargay, J. M. (1992). The irreversible demand effects of high oil prices: Motor petrols in France, Germany, and the UK. In Hawdon, D., editor, Energy Demand: Evidence and Expectations. Academic Press, New York, NY.

[18] Dimitropoulos, J., Hunt, L. C., and Judge, G. (2005). Estimating underlying energy demand trends using UK annual data. Applied Economics Letters, 12(4):239-244.

[19] Donnelly, W. A. (1982). The regional demand for petrol in Australia. Economic Record, 58(163):317-326.

[20] Drollas, L. (1984). The demand for gasoline: further evidence. Energy Economics, 6:71-82.

[21] El-Katiri, L. and Fattouh, B., (2011). Energy poverty in the Arab world: the case of Yemen, MEP1, Oxford Institute for Energy Studies.

[22] El-Katiri, L. and Fattouh, B., (2012) Energy and Arab economic development. United Nations Development Programme, Regional Bureau for Arab States, 2012.

[23] Espey, M. (1998). Gasoline demand revisited: an international meta-analysis of elasticities. Energy Economics, 20(3):273295.

[24] Gately, D. (1991). Imperfect price-reversibility of US gasoline demand: Asymmetric responses to price increases and declines. Economic Research Report RR 91-55, C.V. Starr Center for Applied Economics. New York University.

[25] Goodwin, P., Dargay, J., Hanly, M., 2004. Elasticities of road traffic and fuel consumption with respect to price and income: a review. Transp. Rev. 24 (3), 275-292.

[26] Goodwin, P.B., 1992. A review of new demand elasticities with special reference to short and long run effects of price changes. J. Transp. Econ. Policy 26 (2),155-169.

[27] Graham, D. J. and Glaister, S. (2002). The demand for automobile fuel: A survey of elasticities. Journal of Transport Economics and Policy, 36(1):1-26.

[28] Graham, D. J. and Glaister, S. (2002). The demand for automobile petrol: A survey of elasticities. Journal of Transport Economics and Policy, 36(1):1-26.

[29] Hensher, D. A. and Young, J. L. (1991). Demand forecasts and demand elasticities for australian transport fuel. Occasional paper 103, Bureau of Transport and Communications Economics. Occasional Paper 103.

[30] Hirota, K., Poot, J., Minato, K., (2003). Do policy incentives affect the environmental impact of private car use? Evidence from a sample of large cities. Paper prepared for the 43rd Congress of the European Regional Science Association, Jyvaskyla, Finland.

[31] Houthakker, H. S. and Taylor, L. D. (1966). Consumer Demand in the United States 1929-1970: Analyses and Projections. Cambridge University Press, Cambridge, MA.

[32] Houthakker, H. S. and Taylor, L. D. (2010). Consumer Demand in the United States: Prices, Income, and Consumption Behavior, Third Edition. Springer, New York, NY.

[33] Houthakker, H. S., P. K. Verleger, and D. P. Sheehan (1973) Dynamic Demand Analysis for Gasoline and Residential Electricity. Lexington, Mass. 
[34] Hughes, J. E., Knittel, C. R., and Sperling, D. (2008). "Evidence of a Shift in the Short-Run Price Elasticity of Gasoline Demand," The Energy Journal, International Association for Energy Economics, vol. 29(1), pages 113-134.

[35] Hughes, J.E., Knittel, C.R., Sperling, D., 2008. Evidence of a shift in the short-run price elasticity of gasoline demand. Energy J. 29 (1), 93-114.

[36] Hunt, L. C. and Ninomiya, Y. (2003). Unravelling trends and seasonality: A structural time series analysis of transport oil demand in the UK and Japan. Energy Journal, 24(3):63-97. 17

[37] Huntington, H.G., 2010. Short- and long-run adjustments in U.S. petroleum consumption. Energy Econ. 32 , 63-72.

[38] Hymel, K.M., Small, K.A., 2015. The rebound effect for automobile travel: asymmetric response to price changes and novel features of the 2000s. Energy Econ. 49, 93-103.

[39] Hymel, K.M., Small, K.A., van Dender, K., 2010. Induced demand and rebound effects in road transport. Transp. Res. Part B 44 (10), 1220-1241.

[40] Intrilligator, M. D., Bodkin, R. G., and Hsiao, C. (1996). Econometric models, techniques, and applications. Prentice Hall, Upper Saddle River, NJ, second edition.

[41] Johansson, O., Schipper, L., 1997. Measuring the long-run petrol demand of cars: separate estimations of vehicle stock, mean petrol intensity, and mean annual driving distance. J. Transp. Econ. Policy 31 (3), 277-292.

[42] Jones, C. T. (1993). A single-equation study of U.S. petroleum consumption: The role of model specification. Southern Economic Journal, 59(4):687-700.

[43] Kanjilal, K. and Ghosh, S. (2018). Revisiting income and price elasticity of gasoline demand in India: new evidence from cointegration tests, Empirical Economics, Springer, vol. 55(4), pages 1869-1888, December.

[44] Kayser, H.A., 2000. Gasoline demand and car choice: estimating gasoline demand using household information. Energy Econ. 22, 331-348.

[45] Li, S., Linn, J., Muehlegger, E. (2014). Gasoline Taxes and Consumer Behavior. American Economic Journal: Economic Policy, 6(4), 302-342. doi:10.2307/43189412

[46] Lin, C.C., Prince, L., 2013. Gasoline price volatility and the elasticity of demand for gasoline. Energy Econ. 38, $111-117$.

[47] Nickell, S. (1981). Biases in dynamic models with fixed effects. Econometrica 49(6): 1417-1426

[48] Odeck L., Johansen K., (2016) Elasticities of petrol and traffic demand and the direct rebound effects: an econometric estimation in the case of Norway. Transp. Res. Part A, 83, pp. 1-13.

[49] Perron, P. (1989). The great crash, the oil price shock, and the unit root hypothesis. Econometrica, 57:1361-1401.

[50] Pesaran, M. Hashem, 2015. Time Series and Panel Data Econometrics. Oxford University Press.

[51] Puller, S.L., Greening, L.A., 1999. Household adjustment to gasoline price change: an analysis using 9 years of US survey data. Energy Econ. 21, 37-52.

[52] Romero-Jordan, D., del Rio, P., Jorge-Garcia, M., Burguillo, M., 2010. Price and income elasticities of demand for passenger transport fuels in Spain.

[53] Samimi, R. (1995). Road transport energy demand in Australia. Energy Economics, 17(4):329-339.

[54] Scott, K. R. (2011). Demand and Price Volatility/Forecastability: Rational Habits in International Gasoline Demand. UC-Berkeley Dept. of Agricultural and Resource Economics, CUDARE Working Papers Series 1122

[55] Sentenac-Chemin, E., 2012. Is the price effect on fuel consumption symmetric? Some evidence from an empirical study. Energy Policy 41, 59-65.

[56] Small, K A., and Van Dender K. (2007). Fuel efficiency and motor vehicle travel: The declining rebound effect. The Energy Journal 28(1): 25-51

[57] Sterner, T. and Dahl, C. (1992). Modelling transport petrol demand. In Sterner, T., editor, International Energy Economics, pages 65-79. Chapman and Hall.

[58] Sweeney, J. L. (1979). Effects of federal policies on gasoline consumption. Resouces and Energy, 2:3-26.

[59] Toda, H.Y.; Yamamoto, T. Statistical inference in vector autoregressions with possibly integrated processes. J. Econom. $1995,66,225-250$

[60] Traill, B., Colman, D., and Young, T. (1978). Estimating irreversible supply functions. American Journal of Agricultural Economics, 60:528-531.

[61] Wadud, Z., Graham, D.J., Noland, R.B., 2009. Modelling fuel demand for different socio-economic groups. Appl. Energy $86,2740-2749$

[62] Wadud, Z., Graham, D.J., Noland, R.B., 2010a. Gasoline demand with heterogeneity in household responses. Energy J. $31(1), 47-74$

[63] Wadud, Z., Noland, R.B., Graham, D.J., 2010b. A semiparametric model of household gasoline demand. Energy Econ. $32,93-101$.

[64] West, S.E., Williams, R.C., 2007. Optimal taxation and cross-price effects on labor supply: estimates of the optimal gas tax. J. Publ. Econ. 91, 593-617

[65] Wolffram, R. (1971). Positivistic measures of aggregate supply elasticities: Some new approaches-some critical notes. American Journal of Agricultural Economics, 53:356-359. 